\title{
生活習慣病の予防や改善を目指した時間栄養学
}

\section{Chrono-nutrition Studies on Metabolic Diseases}

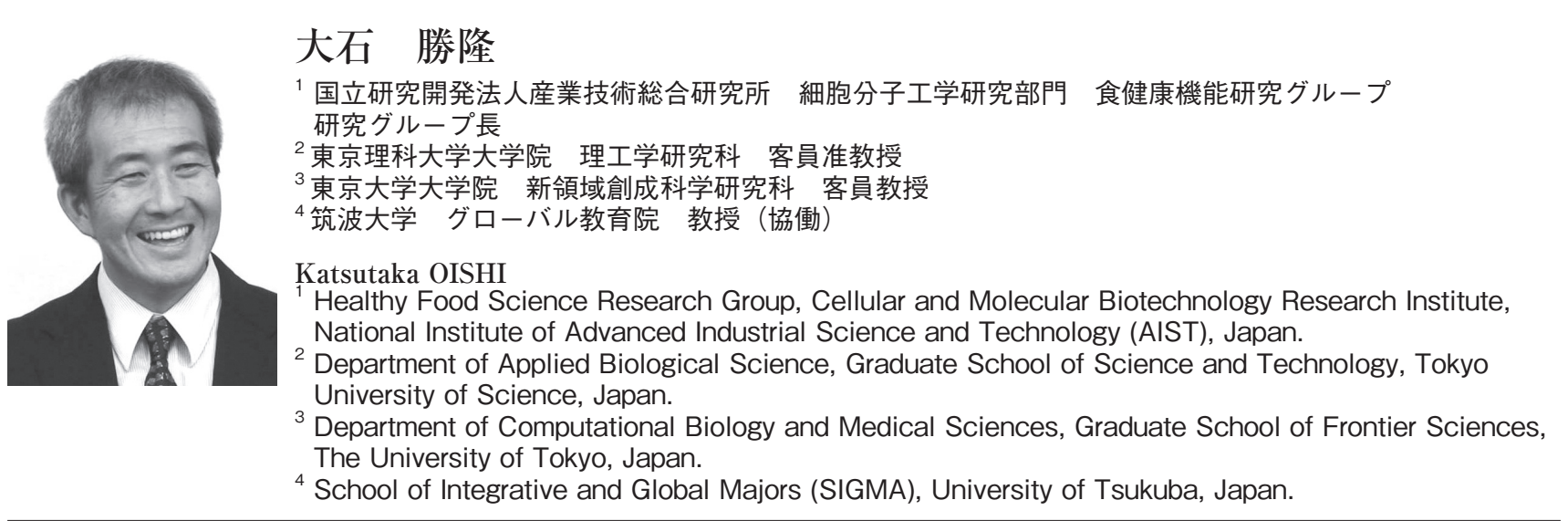

論文要旨：健康の維持増進を目的とした従来の栄養学は, 食品の栄養成分に焦点を当てた, 食事の質と量 に関する研究が中心であった。一方, 食物の消化, 吸収, 代謝機能には日内リズム（サーカデイアンリズム） が存在し，睡眠覚醒リズムや体温のリズムなどとともに，体内時計によって制御されている。従って，これ らのサーカディアンリズムの乱れは, 睡眠障害や生活習慣病などの様々な疾患を引き起こすことが知られて いる。最近になって, 時間栄養学という研究分野が注目されている。時間栄養学とは, 食品の機能性を利用 した睡眠の改善や，生体リズムを利用した食リズムの改善などによって健康機能の向上を目指す学問のこと である。本稿では，時間制限摂食による糖尿病や肥満症などの生活習慣病の改善効果について最近の知見を 紹介する。

\begin{abstract}
The quality and quantity of nutrition are well-accepted determinants of health. On the other hand, endogenous circadian clock governs daily nutritional rhythms such as nutrient digestion, absorption, and metabolism, which are coordinated by behavioral rhythms such as activity-rest and feeding-fasting cycles. Therefore, circadian rhythm disruption causes various physiological impairments such as sleep disorders and metabolic diseases. Chrono-nutrition is the research field that studies the time-of-day effect of food intake on health and that develops the functional food that improves circadian rhythms of physical performance. In the present review, I have tried to summarize the recent studies on the effectiveness of time-restricted feeding on the prevention and improvement of metabolic diseases, such as diabetes and obesity.
\end{abstract}

Key words: chrono-nutrition, diabetes, obesity, time-restricted eating, functional food.

\section{1 体内時計と生体リズム}

バクテリアからヒトに至るまで地球上の多くの生物に は体内時計が存在し，様々な生理機能の概日リズムを制 御している。哺乳類においては, 睡眠覚醒サイクルや, 深部体温, 心拍数, 血圧などの他にも, 自律神経活動や 糖 - 脂質代謝, 免疫機能や血小板凝集能, 細胞分裂, 木 ルモンの分泌などに概日リズムが観察され，その多くが 体内時計によって制御されている（Fig. 1)。コルチゾー

連絡者：大石 勝隆

E-mail :k-ooishi@aist.go.jp
ルやアルドステロンといった副腎皮質ホルモンは, 早朝 の時間帯に分泌が高まり, 睡眠促進作用をもつメラトニ ンは, 夜間に松果体から分泌される。また，肝臓におけ るコレステロール合成は夕刻から夜間にかけて活発にな ることが知られている。このように, 様々な生理機能に 概日リズムが存在することから, いくつかの疾患の発症 や症状にも概日リズムが存在する。例えば, 呼吸機能が 低下する早朝の時間带には, 喘息発作の発症リスクが高 まり, 血小板凝集能が高く, 血液線溶活性が低い午前中 には, 脳梗塞や心筋梗塞といった血栓症のリスクが高ま ることが知られている。痛風発作についても, 血中尿酸 


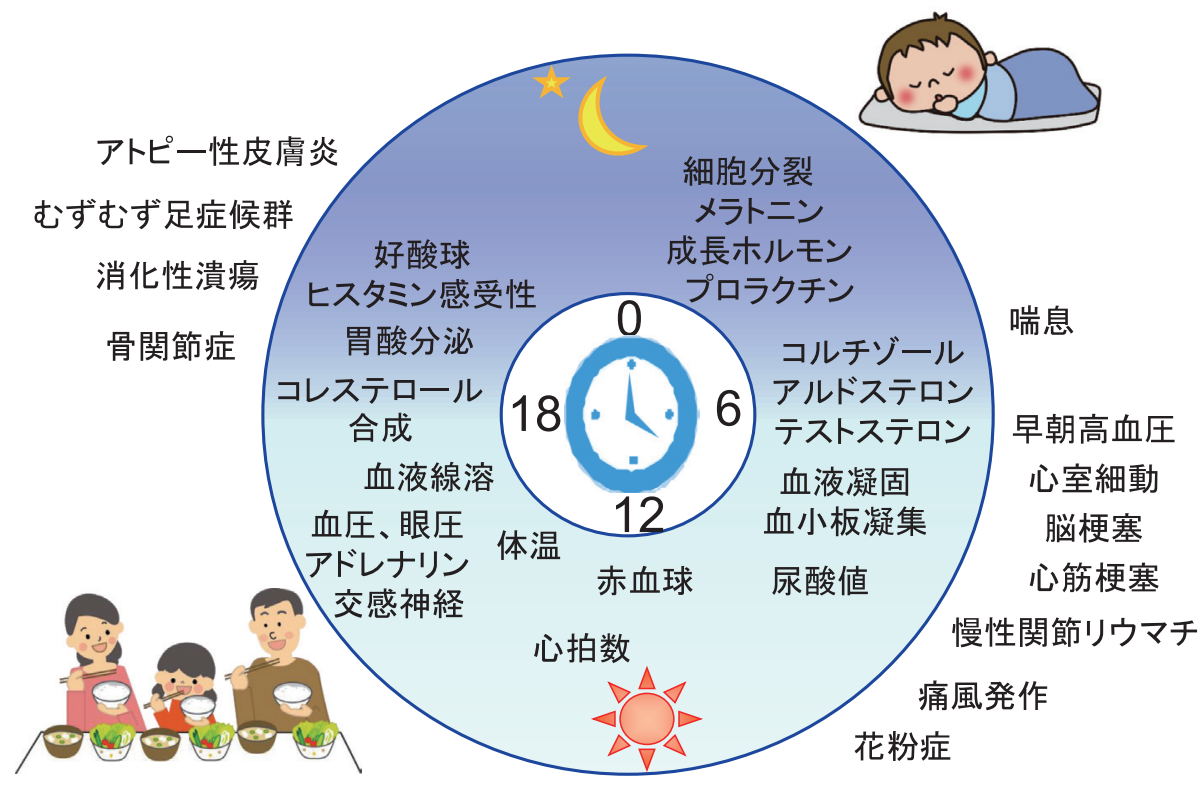

Fig. 1 ヒトの生理機能の日内リズムと疾患の好発時刻

\section{視交叉上核（SCN）の中枢時計が 末梢時計を制御している}

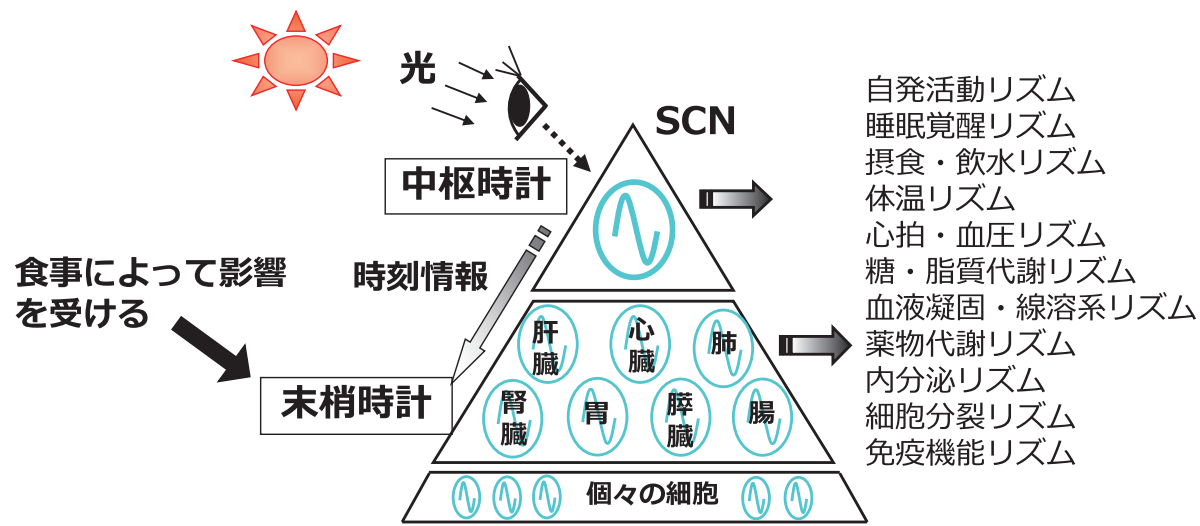

Fig. 2 哺乳類の体内時計の階層構造

值が高くなる早朝が好発時刻となっている。消化性潰瘍 やアトピー性皮膚炎の症状が夜間の前半に重くなること なども知られている。

哺乳類における体内時計の中枢は，脳内視床下部の視 交叉上核 (suprachiasmatic nucleus, SCN) に存在する。 実験動物においてこの神経核を破壊すると，前述したほ とんどの概日リズムが消失する。1990年代後半には, 哺乳類の体内時計が，時計遺伝子とよばれる 10〜20 個 程度の遺伝子によって制御されていることが明らかとな り，時計遺伝子によるリズム発振メカニズムは，時計分 子間の転写・翻訳を介したネガティブフィードバック ループモデルによって説明されている ${ }^{1)}$ 。時計遺伝子の 日周発現は，体内時計の中枢である $\mathrm{SCN}$ のならず, 肝臓や心藏, 腎臓, 骨格筋, 未梢白血球に至るまで, ほ
とんどすべての末梢組織で認められることから, SCN の中枢時計に対して, 末梢時計の存在が明らかとなっ た。時計遺伝子の日周発現は, 培養細胞においても観察 されることから, 個々の細胞にリズムを刻むための要素 がすべて備わっているものと考えられる。その一方で, 個体レベルでは，SCNの中枢時計が，神経系や，イン スリンやグルココルチコイドといった液性因子を時刻情 報として，末梢時計を同調させているものと考えられる (Fig. 2)。

DNA マイクロアレイによる網羅的な発現遺伝子解析 により, 肝臟や脂肪組織などの末梢組織において, 時計 遺伝子以外にも多くの遺伝子の発現量が 1 日の中で変動 していることが明らかとなった。肝臓では，10\%以上の 遺伝子が日周発現しており, 糖新生に関わるP P k \ 糖 


\section{生体リズムの制御}

\section{食品の機能性を利用し、生体リズムを積極的に制御することによ \\ り、体内時計機能や睡眠の改善を目指す栄養学研究}

\section{生体リズムの利用}

体内時計によって制御される消化・吸収・代謝機能の生体リズム を有効に利用し、食品の機能性、特に一次機能（栄養機能）や三 次機能（生体調節機能）、を高めるための摂取方法に関する研究
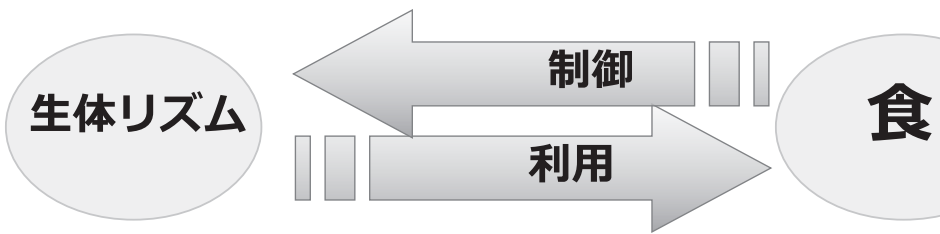

Fig. 3 時間栄養学 (chrono-nutrition)

代謝に関わる Gck，グリコーゲン合成に関わるGys2， コレステロール合成に関わる Hmgcr など, 肝臓の重要 な機能を担っている遺伝子の発現量は，1日の中で大き く変動している。このような臓器特異的な多くの遺伝子 の日周発現が，個体における生理機能の概日リズムを作 り出しているものと考えられる。 SCN の中枢時計が外 界の明暗サイクルに従って時計の針を合わせるのに対し て, 肝臓の末梢時計は, 摂食のリズムによって大きく影 響を受けることが知られている。一方, 骨格筋の時計は, 摂食による影響を受けにくく，SCN からの神経情報に よって時計の針を合わせているようである。従って，夜 食や朝食欠食などの不適切な摂食リズムは，個体内にお ける中枢時計と末梢時計，あるいは末梢時計間の脱同調 を引き起こし, 生体リズムの乱れや疾患の発症につなが るものと考えられる。

\section{2 時間栄養と糖尿病}

近年, 時間栄養学という研究分野が注目されている。 従来の栄養学では, 疾患の予防や健康の維持増進のため に，「何をどれだけ食べるべきか」といった問題に重点 が置かれてきたが, 時間栄養学では,「いつ食べるべきか」 といった新たな視点が加わることとなる。時間栄養学に は, 大きく 2 つの方向性が存在し, 食品や食品成分の機 能性を利用することによって，生体リズムや睡眠の改善 を目指す研究と, 体内時計によって制御されている消化. 吸収・代謝などの生体リズムを利用して, 食品の一次機 能 (栄養機能) や三次機能（生体防御, 代謝改善, 老化 制御, 疾患の予防・回復などの生体調節機能）の改善や
向上を目指す研究である（Fig. 3）。食品の機能性を利用 した時間栄養学では, 2015 年に始まった食品の新たな 機能性表示制度により, これまでに多くの睡眠改善効果 を有する食品が商品化されている ${ }^{2)}$ 。

ヒトや実験動物を対象とした多くの研究により，時間 制限摂食が, 肥満症や糖尿病などの生活習慣病の予防や 改善に効果がある可能性が示されている ${ }^{3)}$ 。例えば, 朝 食欠食が, 血中 LDL コレステロールの増加や脂肪の蓄 積のみならず, 糖尿病の発症リスクを増加させる一方で, 1日の食事を 16:00 までに終わらせる時間制限摂食(アー リーダイニングとも言われる) は, 肥満や糖尿病の発症 リスクのみならず, 血圧や冠状動脈性心疾患の発症リス クも低減させる ${ }^{4)}$ 。糖尿病予備軍の男性を対象とした 6 時間の時間制限摂食 $(8: 00 \sim 14: 00)$ では， 5 週間後に， 酸化ストレスの減少や血圧の低下, インスリン感受性の 改善が認められている ${ }^{5)}$ 。肥満者を対象としたランダム 化クロスオーバー試験では，早い時間帯 $(8: 00 \sim 17$ : 00）の時間制限摂食と遅い時間帯（12：00〜21：00）の 時間制限摂食の糖代謝改善効果を比較したところ, 7 日 後には両群ともに食後血糖值や空腹時中性脂肪の低減が 認められた一方で, 空腹時血糖值の減少は, 早い時間帯

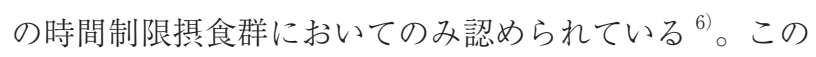
ように，時間制限摂食による代謝改善効果には，食事の タイミングと絶食時間の長さの 2 つの要素が重要であ り, これらの時間栄養学的アプローチにより, 薬物に依 存しない生活習慣病の予防や改善が可能かもしれない。

インスリンの感受性には朝に高まる日内リズムが存在 し，同じ食事を摂取した場合，血糖值の上昇は夕食時に 
比べて朝食時に抑制されることが知られている。また最 近では，野菜から先に食べる「ベジファースト」が血糖 值の急激な上昇を抑えて，血糖值の上昇に伴うインスリ ンの分泌を緩やかにする健康法として定着してきている が，1日のうちで最初に摂った食事が，次の食事の際の 食後血糖值に影響するという「セカンドミール効果」7) が注目されている。これは, 1 日の最初に, 糖質が少な めで食物繊維を豊富に含む食事を摂取すると，2回目の 食事においても食後血糖值の上昇を抑制する効果がある というものである。実際，同じエネルギー量の食事を 1 日 3 回摂取した場合と朝食欠食により 2 回しか摂取しな かった場合で比較すると，朝食欠食群では 1 食分の摂取 エネルギーが少ないのにも関わらず，昼食後の血糖值が 大きく上昇し，1日の平均血糖值が両群間で等しくなっ た ${ }^{8)}$ 。夕食のタイミングについても血糖コントロールに とって重要であり，健常者を対象に，朝食と昼食の時刻 を揃えて, 夕食のみを就寝 4 時間前と就寝 30 分前に摂 取させた場合で比較すると，1日のエネルギー代謝が同 一であった一方で，1日の平均血糖值や翌朝の朝食後血 糖值が後者で有意に高值を示した ${ }^{9)}$ 。従って, 糖尿病の 予防や改善のためには, 食物繊維の豊富な朝食を摂るこ とと, 就寝直前の夕食の摂取を避けることが重要である。

\section{3 時間栄養と肥満症}

肥満は，主にエネルギーの供給が消費に対して過剩と なることによって生じ, 過食などの食行動の異常や, 肝 臓や脂肪, 骨格筋などのエネルギー代謝臓器での脂質代 謝異常などが原因となっている。一方，エネルギー代謝 （基礎代謝）には，活動期に高く，睡眠時（非活動期） に低くなる日内リズムが存在する。このエネルギー代謝 の日内リズムは, 活動のリズムに起因するものではなく, 体内時計によって直接的に制御されている ${ }^{10)}$ 。エネル ギー代謝の日内リズムと関連して，食事誘発性熱産生 (Diet-induced Thermogenesis, DIT) にも日内リズム が存在し ${ }^{11)}, 7: 00,13: 00,19: 00$ に同一カロリーの 食事を摂取した場合，7:00の DIT が最も高值を示す ${ }^{12)}$ 。

前述のように, 朝食欠食や生活リズムの夜型化などに よる摂食リズムの乱れは, 肥満症のリスクを増大させる ${ }^{3)}$ 。 動物を用いた研究においても，活動リズムに一致した時 間制限給飭によって肥満が抑制され ${ }^{13)}$ ，活動リズムに

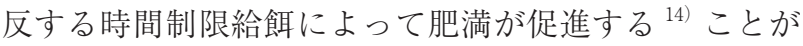
報告されていたが，そのメカニズムについては不明で あった。我々は，マウスを用いた時間制限給慨実験によ り，摂食のタイミングと食餌性肥満との関連性について 実験を行った。活動期である暗期にのみ高脂肪高ショ糖 食を食べさせたマウス（活動期摂飰群）と非活動期であ
る明期にのみ高脂肪高ショ糖食を食べさせたマウス（非 活動期摂䭒群）で比較を行ったところ, 活動期摂餌群に 比べて非活動期摂餌群では, 摂取する飭の量はほとんど 等しいにもかかわらず，たった 1 週間で脂肪蓄積の増加 に伴う体重増加が認められた。また, 遺伝子発現解析の 結果からは, 非活動期摂餌群の肝臓や脂肪組織では, 脂 肪酸合成が立進している可能性が認められた。以上の結 果より，非活動期（ヒトにおける夜間）の摂食は，短期 間で脂肪の蓄積を伴う肥満を促進する可能性が考えられ た ${ }^{15)}$ 。興味深いことに，この非活動期の摂食による肥 満には，運動習慣による改善効果が認められないばかり か $^{16)}$ ，骨格筋の萎縮を伴う筋力の低下も認められ ${ }^{17)}$, 適切なタイミングでの摂食は，肥満や筋萎縮などによる 生活習慣病の予防や改善に重要であると思われる。

非活動期の時間制限給餌は内分泌系にも影響し，レプ チン（摂食によって脂肪細胞から分泌され，視床下部に 作用することで，食欲を抑制するとともに全身の代謝を 促進するホルモン）の作用を強く障害する（レプチン抵 抗性）ことを明らかにした。さらに，このレプチン抵抗 性のモデル動物である $d b / d b$ マウス（レプチン受容体 の遺伝的変異マウス）においては, 非活動期時間制限給 餌の影響を受けないことから, 非活動期の摂食による肥 満の促進には, レプチン抵抗性が関与している可能性を 明らかにした ${ }^{18)}$ (Fig.4)。

\section{4 機能性食品による代謝改善効果と時間栄養}

代謝改善を目的とした機能性食品が数多く存在する が，その至適摂取時刻に関しては，これまでほとんど明 らかにされてこなかった。我々は, 食品成分の機能性に 関する時間栄養学研究として, 脂質代謝改善効果を有す るドコサヘキサエン酸（DHA）やエイコサペンタエン 酸（EPA）を含む魚油に着目し，摂取時刻の違いがそ の機能性に与える影響について検討を行った ${ }^{19)}$ 。肝蔵 への脂肪の蓄積を促進する高果糖食と, 魚油を含む高果 糖食を用意し, マウスを 3 群 (終日高果糖食を与えた「対 照群」，マウスにとって朝食に該当する活動開始の時間 帯のみ魚油の入った慨を与え, 残りの時間は高果糖食を 与えた「魚油朝摂取群」, マウスにとって夕食に該当す る活動終了の時間帯のみ魚油の入った餌を与え, 残りの 時間は高果糖食を与えた「魚油夕摂取群」）に分けて 2 週間の飼育を行った。その結果, 血液中の魚油成分 (DHA や EPA）濃度は, 魚油朝攝取群において夕摂取群に比 べて有意に高值となっており, 血液中や肝臓中の中性脂 肪低減効果も, 朝摂取群で有意に認められた。糞便を用 いた解析により,活動開始時間帯（ヒトにおける朝食時） には，魚油の吸収効率が高くなっていることが判明した 


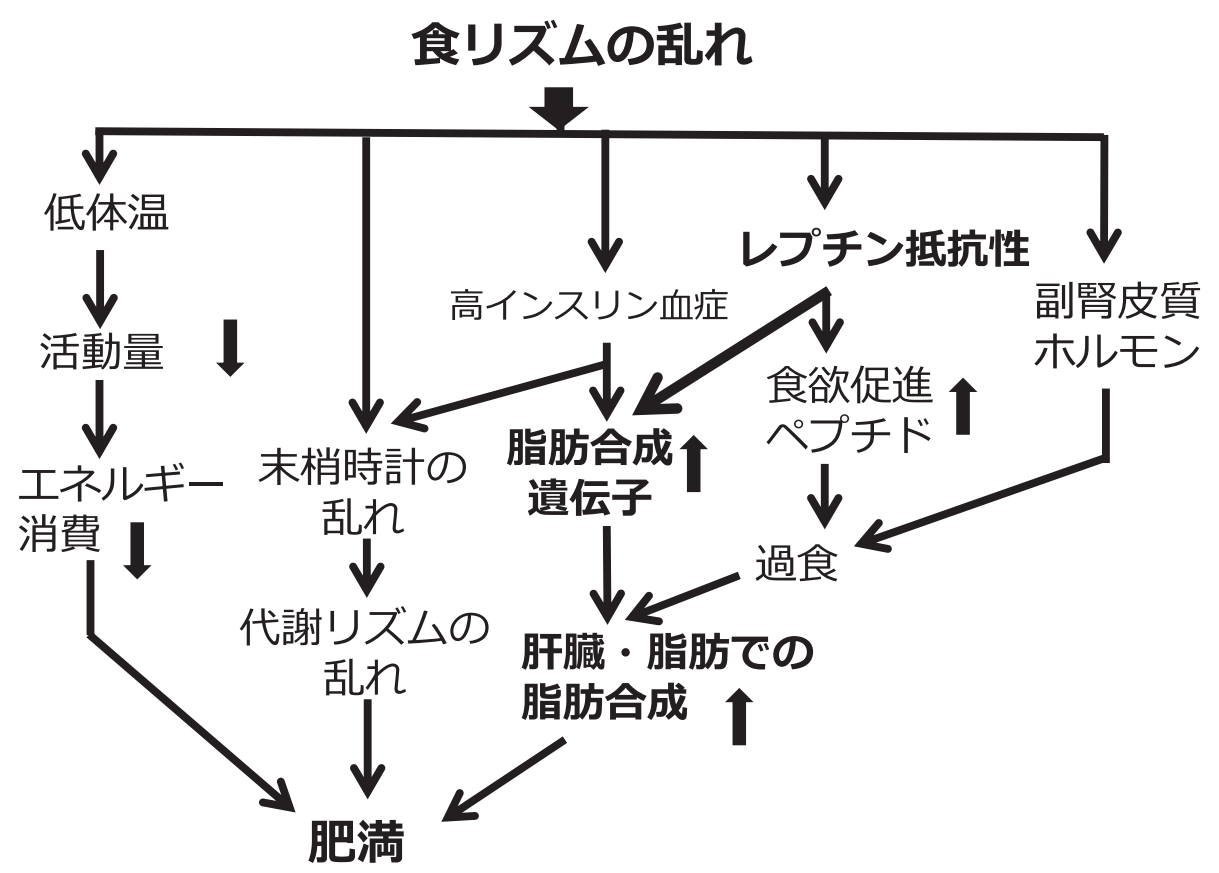

Fig. 4 食リズムの乱れに伴う肥満促進のメカニズム

血液中DHA濃度

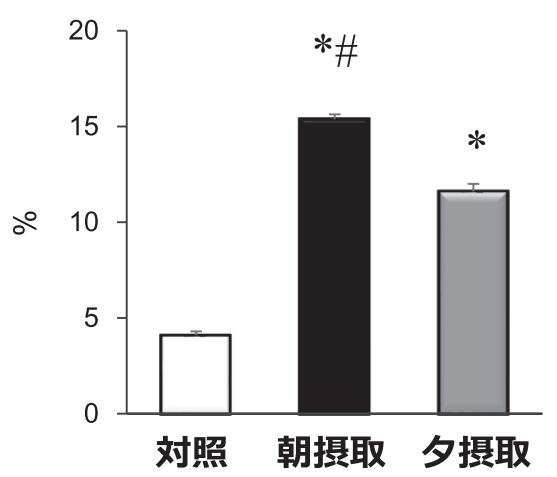

血液中の中性脂肪

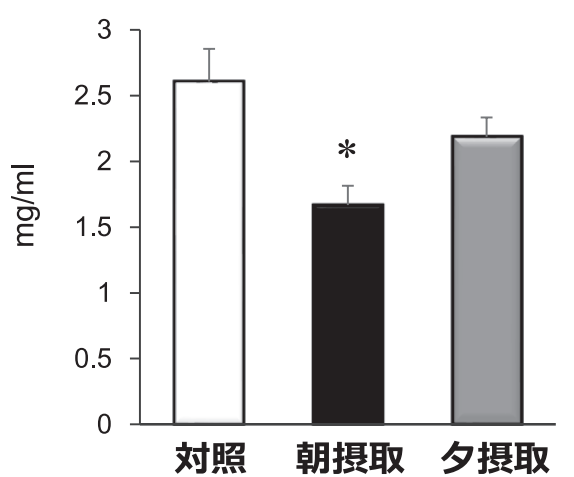

血液中EPA濃度

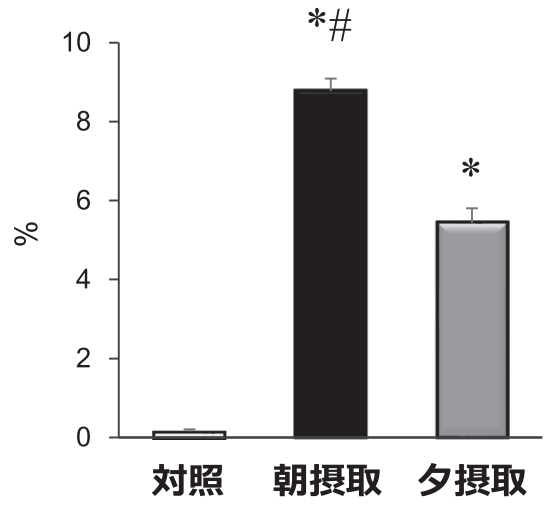

肝臓中の中性脂肪

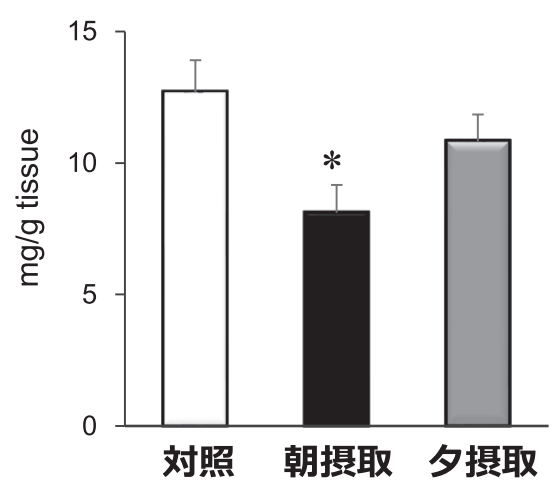

Fig. 5 魚油の摂取時刻の違いが脂質代謝改善効果に及ぼす影響。 ${ }^{*} p<0.05$ 対照群との比較, ${ }^{*} p<0.05$ 夕摂取群との比較。

(Fig. 5)。

そこで，ヒトにおいても魚油による脂質代謝改善効果
に摂取時刻が影響する可能性を調べることとした。 DHA と EPA を強化した魚肉ソーセージとプラセボソー 
セージを用いて, 朝夕 1 本ずつ 8 週間摂取してもらった ところ, DHA・EPA 強化ソーセージを朝に摂取した群 において, 中性脂肪やコレステロール，飽和脂肪酸の低 減効果が強く認められた。従って，ヒトにおいても，摂 取時刻の違いが魚油の機能性に影響する可能性が考えら れる(論文投稿中)。

DHA や EPA には, 大腸の GPR120 という受容体を 介してインクレチン GLP-1の分泌を促進させる効果が 報告されている ${ }^{20)}$ 。インスリンは末梢時計のリセット 効果を有しており, 朝の魚油の摂取は, GLP-1 分泌を介 した膵 $\beta$ 細胞からのインスリン分泌を誘導することに より，末梢時計のリセットに寄与している可能性が考え られる ${ }^{20)}$ 。

ゴマに含まれるセサミンには，血中や肝臓中の中性脂 肪やコレステロールを低減させる効果が知られている。 高脂肪食を負荷したラットに対するセサミン投与の実験 では，セサミンを活動開始時刻に摂取させた方が，活動 終了時刻に摂取させた場合に比べて，コレステロール代 謝の改善効果が高まることが報告されている ${ }^{21)} 。$

リコピンはトマトに含まれるカロテノイドであり，抗 酸化作用によりさまざまな疾患の予防効果が知られてい る。リコピンの吸収に対する摂取時刻の影響について,

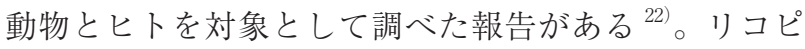
ンは, 動物でもヒトでも活動期の初期に吸収が高まるこ とが示され，さらに，摂取前の絶食時間に依存して吸収 が高まることが報告されているが，今のところその分子 メカニズムは不明である。

緑茶の主要なポリフェノールであるカテキンには, 血 糖值の降下作用が知られている。濃カテキン緑茶の食後 血糖值の抑制効果を朝食時と夕食時で比較したところ, インスリンの分泌に対しては朝夕で差異が認められな かった一方で, 血糖值の上昇は, 夕食時の緑茶摂取によっ て顕著に抑制されることが報告されている ${ }^{23,24)}$

近年, 腸内細菌叢の乱れが宿主の代謝, 免疫, 脳機能 などに影響することが明らかとなってきた。次世代シー ケンサーを用いた網羅的な解析により, 腸内細菌叢が 1 日の食餌のリズムに従ってダイナミックに変動している ことも知られている。大豆タンパク質 ${ }^{25)}$ や、ゴボウや 菊芋に含まれる水溶性食物繊維イヌリン ${ }^{26)}$ のプレバイ オティクス効果について, マウスを用いて朝夕で比較し た研究があり，ともに朝食時の摂取の方が効果的である ことが報告されている。興味深いことに，イヌリンを多 く含むゴボウによるプレバイオティクス効果について は，上記と同様のマウスを使った実験により，夕食時の 摂取がより効果的であることが報告されており ${ }^{27)}$ ，同 一の機能性成分であっても，その成分を含有する食品の
種類や形態によって，摂取する至適タイミングが異なる 可能性も考えられる。

\section{5 おわりに}

超高齢社会の到来によって, 健康寿命の延伸は喫緊の 課題となっている。生活習慣病や睡眠障害などの様々な 疾患に対しては, 発症を未病段階で予防することが重要 であると考えられる。時間栄養学は, 食育やシフトワー クの効率化などを通して QOL の向上に広く貢献するも のと期待される。

\section{文 献}

1) Weaver, D.R. J. Biol. Rhythms. 13, 100-112 (1998).

2）大石勝隆. アグリバイオ 4, 618-622 (2020). (Oishi, K. Agricultural biotechnology 4, 618-622 (2020))

3) Chaix, A.; Manoogian, E.N.C.; Melkani, G.C.; Panda, S. Annu. Rev. Nutr. 39, 291-315 (2019).

4) Paoli, A.; Tinsley, G.; Bianco, A.; Moro, T. Nutrients 11, 719 (2019).

5) Sutton, E.F.; Beyl, R.; Early, K.S.; Cefalu, W.T.; Ravussin, E.; Peterson, C.M. Cell Metab. 27, 1212-1221.e3 (2018).

6) Hutchison, A.T.; Regmi, P.; Manoogian, E.N.C.; Fleischer, J.G.; Wittert, G.A.; Panda, S.; Heilbronn, L.K. Obesity (Silver Spring) 27, 724-732 (2019).

7) Jenkins, D.J.; Wolever, T.M.; Taylor, R.H.; Griffiths, C.; Krzeminska, K.; Lawrie, J.A.; Bennett, C.M.; Goff, D.V.; Sarson, D.L.; Bloom, S.R. Am. J. Clin. Nutr. 35, 13391346 (1982).

8) Ogata, H.; Hatamoto, Y.; Goto, Y.; Tajiri, E.; Yoshimura, E.; Kiyono, K.; Uehara, Y.; Kawanaka, K.; Omi, N.; Tanaka, H. Br. J. Nutr. 122, 431-440 (2019).

9) Sato, M.; Nakamura, K.; Ogata, H.; Miyashita, A.; Nagasaka, S.; Omi, N.; Yamaguchi, S., Hibi, M.; Umeda, T.; Nakaji, S.; Tokuyama, K. Obes. Res. Clin. Pract. 5 , e169-266 (2011)

10) Zitting, K.M.; Vujovic, N.; Yuan, R.K.; Isherwood, C.M.; Medina, J.E.; Wang, W.; Buxton, O.M.; Williams, J.S.; Czeisler, C.A.; Duffy, J.F. Curr. Biol. 28, 3685-3690.e3 (2018).

11) Morris, C.J.; Garcia, J.I.; Myers, S.; Yang, J.N.; Trienekens, N.; Scheer, F.A. Obesity (Silver Spring) 23, 20532058 (2015).

12）関野由香, 柏絵理子, 中村丁次. 日本栄養 - 食糧学会 誌 63, 101-106 (2010). (Sekino, Y. et al. Nippon Eiyo Shokuryo Gakkaishi 63, 101-106 (2010))

13) Hatori, M.; Vollmers, C.; Zarrinpar, A.; DiTacchio, L.; Bushong, E.A.; Gill, S.; Leblanc, M.; Chaix, A.; Joens, M.; Fitzpatrick, J.A.; Ellisman, M.H.; Panda, S. Cell Metab. 15, 848-860 (2012).

14) Arble, D.M.; Bass, J.; Laposky, A.D.; Vitaterna, M.H.; Turek, F.W. Obesity (Silver Spring) 17, 2100-2102 (2009).

15) Yasumoto, Y.; Hashimoto, C.; Nakao, R.; Yamazaki, H.; 
Hiroyama, H.; Nemoto, T.; Yamamoto, S.; Sakurai, M.; Oike, H.; Wada, N.; Yoshida-Noro, C.; Oishi, K. Metabolism 65, 714-727 (2016).

16) Okauchi, H.; Hashimoto, C.; Nakao, R.; Oishi, K. Chronobiol. Int. 36, 57-74 (2019).

17) Abe, T.; Kazama, R.; Okauchi, H.; Oishi, K. Arch. Biochem. Biophys. 677, 108160 (2019).

18) Oishi, K.; Hashimoto, C. Chronobiol. Int. 35, 1576-1594 (2018).

19) Oishi, K.; Konishi, T.; Hashimoto, C.; Yamamoto, S.; Takahashi, Y.; Shiina, Y. J. Nutr. Biochem. 52, 45-53 (2018).

20) Furutani, A.; Ikeda, Y.; Itokawa, M.; Nagahama, H.; Ohtsu, T.; Furutani, N.; Kamagata, M.; Yang, Z.H.; Hirasawa, A.; Tahara, Y.; Shibata, S. PLoS One 10, e0132472 (2015).

21) Tateishi, N.; Morita, S.; Yamazaki, I.; Okumura, H.; Kominami, M.; Akazawa, S.; Funaki, A.; Tomimori, N.;
Rogi, T.; Shibata, H.; Shibata, S. Chronobiol Int. 37, 493509 (2020).

22）青木雄大, 吉田和敬, 信田幸大, 砂堀諭, 西田由香, 加藤秀夫, 菅沼大行. 日本栄養 · 食糧学会誌 70, 147155 (2017). (Aoki, Y. et al. Nippon Eiyo Shokuryo Gakkaishi 70, 147-155 (2017))

23) Takahashi, M.; Ozaki, M.; Miyashita, M.; Fukazawa, M.; Nakaoka, T.; Wakisaka, T.; Matsui, Y.; Hibi, M.; Osaki, N.; Shibata, S. J. Nutr. Biochem. 73, 108221 (2019).

24) Takahashi, M.; Ozaki, M.: Tsubosaka, M.; Kim, H.K.; Sasaki, H.; Matsui, Y.; Hibi, M.; Osaki, N.; Miyashita, M.; Shibata, S. Nutrients 12, 565 (2020).

25) Tamura, K.; Sasaki, H.; Shiga, K.; Miyakawa, H.; Shibata, S. Nutrients 12, 87 (2019).

26) Sasaki, H.; Miyakawa, H.; Watanabe, A.; Nakayama, Y.; Lyu, Y.; Hama, K.; Shibata, S. Nutrients 11, 2802 (2019).

27) Watanabe, A.; Sasaki, H.; Miyakawa, H.; Nakayama, Y.; Lyu, Y.; Shibata, S. Microorganisms 8, 220 (2020). 